[Agr. Biol. Chem., Vol. 25, No. 5, p. 410 416, 1961]

\title{
Studies on the Amino Acids Fermentation of Pentose Materials
}

\author{
Part II. Formation of Amino Acids from Pentoses and Hexoses \\ By Brevibacterium pentoso-aminoacidicum nov. sp.
}

By Yoshio Hirose and Kōichi Yamada

Department of Agricultural Chemistry, Faculty of Agriculture, University of Tokyo

Received December 28, 1960

\begin{abstract}
Fundamental studies on the cultural conditions for the amino acids production from pentoses and hexoses employing a strain of our new isolates named Brevibacterium pentosoaminoacidicum nov. sp. were carried out.

As a result of these experiments, it became possible to obtain about $30 \%$ of alanine and $10 \%$ of L-glutamic acid based on xylose, and alanine from glucose with a yield of about $40 \%$ in the proper conditions.
\end{abstract}

\section{INTRODUCTION}

In a previous paper ${ }^{1)}$, we discussed the morphological and physiological properties of a new group of Brevibacterium isolated from soils and capable of producing amino acids from pentoses and hexoses. These new isolates were classified into two species: Brevibacterium pentoso-aminoacidicum and Brevibacterium pentoso-alanicum. Brev. pentosoaminoacidicum was found to produce remarkable amounts of L-glutamic acid and alanine from pentoses and hexoses. Brev. pentosoalanicum was shown to be able to convert these sugars into alanine with a high yield.

In both cases, ammonium salts were adopted as a nitrogen source.

The present paper concerns the fermentative production of L-glutamic acid and alanine from pentoses and hexoses by Brev. pentosoaminoacidicum. The fundamental studies were carried out with the intension of finding out the adequate conditions for the fermentative production of these amino acids.

1) K. Yamada and Y. Hirose, This Journal, 24, 621 (1960).

\section{EXPERIMENTAL METHODS}

Microorganisms. Brevibacterium pentoso-aminoacidicum nov. sp. was used throughout the experiments.

Analytical Methods. For the qualitative analysis of amino acids, the method of ascending paper chromatography using a mixture of $n$-butanol, acetic acid and water $(4: 1: 4$ by vol.) as a solvent followed by the detection of spots by the ninhydrin solution was adopted.

Quantitative analysis of L-glutamic acid was accomplished by the microbioassay method using Lactobacillus arabinosus $17-5^{2}$ ) and the manometric method with the L-glutamic decarboxylase preparation obtained from the culture of Escherichia coli Crookes $^{8)}$.

Alanine was determined by the microbioassay method using Leuconostoc citrovorum $8081^{2}$.

Xylose and glucose were analysed by Somogyi-ShafferHartman's method').

The extent of cell growth was expressed by the optical density at $562 \mathrm{~m} \mu$ of the culture broth diluted to one twenty sixth with water.

Organic acids were separated by the method of paper chromatography with the use of a mixture of $n$-butanol, formic acid and water $(4: 1: 1.5$ by vol.)

\footnotetext{
2) T. Tsunoda, Protein Chemistry, 1, 282 (1954).

3) W. Umbreit, R. Burris and J. Stauffer, "Manometric Techniques", 1957 , p. 207.

4) P. Schaffer and M. Somogyi, J. Biol. Chem., 100, 695 (1933).
} 
as a solvent and the spots were detected with a bromphenol blue solution. The detection of $a$-ketoglutaric acid and pyruvic acid was performed by the paper chromatography of their hydrazones with $n$-butanol saturated with water.

Methods of Fermentation Tests. Unless otherwise stated, the fermentation tests were conducted in the following way: Cultures were performed with $20 \mathrm{ml}$ of the medium in $500 \mathrm{ml}$ flasks and incubated at $30^{\circ} \mathrm{C}$ on a reciprocal shaker at a rate of 144 r.p.m. After 120 hours' incubation, the cells were filtered off and the filtrates were subjected to analysis.

\section{EXPERIMENTAL RESULTS AND DISCUSSION}

\section{(I) The Influence of Nitrogen Sources.}

With the intension of finding out the proper nitrogen sources for the production of amino acids, several compounds containing nitrogen were examined. The compounds examined in these experiments are the following twelve substances: $\mathrm{NH}_{4} \mathrm{Cl},\left(\mathrm{NH}_{4}\right)_{2} \mathrm{SO}_{4}$, $\mathrm{NH}_{4} \mathrm{H}_{2} \mathrm{PO}_{4},\left(\mathrm{NH}_{4}\right)_{2} \mathrm{HPO}_{4}$, ammonium tartarate, ammonium acetate, ammonium citrate, $\mathrm{KNO}_{3}, \mathrm{NaNO}_{3}, \mathrm{NaNO}_{2}, \mathrm{NH}_{4} \mathrm{NO}_{3}$ and urea.

For these experiments, the basal medium was composed of $5.0 \mathrm{~g}$ of xylose, $0.1 \mathrm{~g}$ of $\mathrm{K}_{2} \mathrm{HPO}_{4}, 0.05 \mathrm{~g}$ of $\mathrm{MgSO}_{4} \cdot 7 \mathrm{H}_{2} \mathrm{O}$ and $0.05 \mathrm{~g}$ of peptone in $100 \mathrm{ml}$ of tap water. The $\mathrm{pH}$ was adjusted to 7.0. The results are shown in Table $\mathrm{I}$.

No growth was observed when $\mathrm{NaNO}_{2}$, ammonium tartarate, ammonium acetate and ammonium citrate were used. And it was found that this strain has rather low assimilability of nitrates. Urea as well as the ammonium salts of the inorganic acids, $\left(\mathrm{NH}_{4}\right)_{2} \mathrm{SO}_{4}$ and $\mathrm{NH}_{4} \mathrm{Cl}$, were proved to be good nitrogen sources. Accordingly, urea was adopted for the nitrogen sources in the following experiments.

\section{(II) The Influence of Urea Concentration.}

The concentration of the nitrogen sources was supposed to be important for amino acids production and the effect of the concentration of urea was examined. The results were as follows (Fig. 1) :

The basal medium employed was the same as before. As shown in the figure, the yield of alanine was much influenced by the nitro-

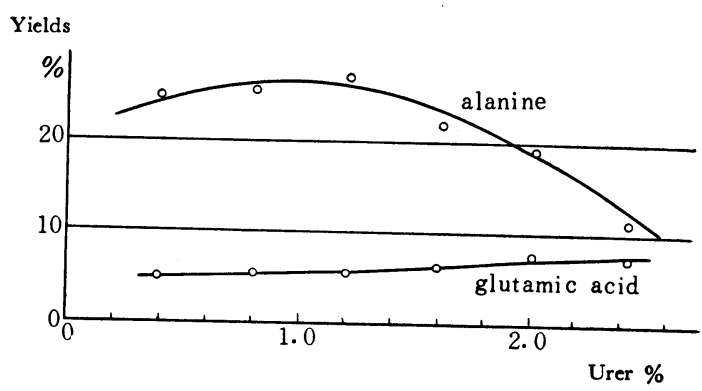

FIG. 1. Influence of Urea Concentration on the Production of Amino Acids.

Table I. Influence of Nitrogen sources on the Production of Amino Acids

\begin{tabular}{|c|c|c|c|c|c|}
\hline \multirow{2}{*}{ N-Sources } & \multirow{2}{*}{$\underset{\%}{\mathrm{~N}-S o u r c e s}$} & \multirow{2}{*}{ M.W. } & \multirow{2}{*}{$\mathrm{N}-\%$} & \multicolumn{2}{|c|}{ Yields based on the sugar added } \\
\hline & & & & Alanine \% & Glutamic acid \% \\
\hline $\mathrm{NH}_{4} \mathrm{Cl}$ & 1.5 & 53.5 & 0.38 & 14.6 & 5.2 \\
\hline $\mathrm{NH}_{4} \mathrm{NO}_{3}$ & 1.1 & 80.1 & 0.38 & 5.2 & 2.1 \\
\hline$\left(\mathrm{NH}_{4}\right)_{2} \mathrm{SO}_{4}$ & 1.8 & 132.1 & 0.38 & 10.8 & 5.2 \\
\hline $\mathrm{KNO}_{3}$ & 2.7 & 101.1 & 0.38 & 3.1 & 0 \\
\hline $\mathrm{NaNO}_{3}$ & 2.3 & 85.0 & 0.38 & 2.8 & 0 \\
\hline $\mathrm{NaNO}_{2}$ & 1.8 & 69.0 & 0.38 & 0 & 0 \\
\hline $\mathrm{NH}_{4} \mathrm{H}_{2} \mathrm{PO}_{4}$ & 3.0 & 115.0 & 0.38 & 10.2 & 5.3 \\
\hline$\left(\mathrm{NH}_{4}\right)_{2} \mathrm{HPO}_{4}$ & 1.8 & 132.1 & 0.38 & 8.1 & 4.0 \\
\hline $\mathrm{NH}_{4}$-tart. & 2.5 & 184.0 & 0.38 & 0 & 0 \\
\hline $\mathrm{NH}_{4}$-acet. & 2.0 & 77.1 & 0.38 & 0 & 0 \\
\hline $\mathrm{NH}_{4}$-citr. & 2.2 & 243.2 & 0.38 & 0 & 0 \\
\hline Urea & 0.8 & 60.1 & 0.38 & 24.7 & 8.1 \\
\hline
\end{tabular}


gen concentration but the yield of L-glutamic acid only slightly. The optimal concentration of urea for alanine production was observed to be $0.6 \sim 1.0 \%$ (corresponding to $0.3 \sim 0.5 \%$ $\mathrm{N})$. Addition of too much urea caused the remarkable decrease of alanine formation and it was supposed that this was the result of the unfavorable change of $\mathrm{pH}$ of the culture broth owing to the strong urease activity of this strain. In the following experiments, therefore, the initial concentration of urea was fixed at $0.6 \sim 0.8 \%$ and in the course of the fermentation the feeding of this nitrogen compound was performed to maintain the moderate $\mathrm{pH}$ value and also to supply the nitrogen.

The optimal concentration of urea, when the feeding method was not employed, was about $0.8 \%$ (corresponding to $0.4 \% \mathrm{~N}$ ), and carbon-nitrogen ratio of this medium was about $100: 25$.

\section{(III) The Influence of Growth Substances.}

It was supposed that the growth substances requirement of this strain was rather low and the addition of the slight amounts of these substances was effective for the amino acids production as well as for the growth. To ascertain this, the effects of five common organic substances, peptone, yeast extract, meat extract, corn-steep liquor and casate, were examined.

In this experiment, the basal medium was composed of $5.0 \mathrm{~g}$ of xylose, $0.1 \mathrm{~g}$ of $\mathrm{K}_{2} \mathrm{HPO}_{4}$, $0.05 \mathrm{~g}$ of $\mathrm{MgSO}_{4} \cdot 7 \mathrm{H}_{2} \mathrm{O}$ and $0.6 \mathrm{~g}$ of urea in $100 \mathrm{ml}$ of tap water and to this basal medium these substances were added at three levels of concentration. The results summarized in Table II show that peptone and casate are proper growth substances for amino acids production. It is also evident that addition of too much of these compounds caused the decrease of the amino acids formation. And it is interesting that in some cases no glutamic
TABLE II. INFLUENCE OF GROWTH SUBSTANCES oN THE PRODUCTION OF AMINO ACIDS

\begin{tabular}{|c|c|c|c|}
\hline \multirow{2}{*}{$\begin{array}{l}\text { Substances } \\
\text { added }\end{array}$} & \multirow{2}{*}{$\%$} & \multicolumn{2}{|c|}{$\begin{array}{l}\text { Yields based on } \\
\text { the sugar added }\end{array}$} \\
\hline & & $\underset{\%}{\operatorname{Alanine}}$ & $\begin{array}{l}\text { Glutamic } \\
\text { acid } \%\end{array}$ \\
\hline Peptone & $\left\{\begin{array}{l}0.05 \\
0.1 \\
0.2\end{array}\right.$ & $\begin{array}{r}24.7 \\
16.2 \\
8.0\end{array}$ & $\begin{array}{r}8.1 \\
10.2 \\
8.5\end{array}$ \\
\hline Yeast extract & $\left\{\begin{array}{l}0.05 \\
0.1 \\
0.2\end{array}\right.$ & $\begin{array}{r}13.3 \\
8.5 \\
7.3\end{array}$ & $\begin{array}{l}0 \\
0 \\
2.2\end{array}$ \\
\hline Meat extract & $\left\{\begin{array}{l}0.05 \\
0.1 \\
0.2\end{array}\right.$ & $\begin{array}{r}10.2 \\
9.1 \\
7.1\end{array}$ & $\begin{array}{l}2.0 \\
2.2 \\
2.3\end{array}$ \\
\hline G.S.L. & $\left\{\begin{array}{l}0.05 \\
0.1 \\
0.2\end{array}\right.$ & $\begin{array}{r}10.7 \\
8.7 \\
8.0\end{array}$ & $\begin{array}{l}0 \\
0 \\
0\end{array}$ \\
\hline Gasate & $\left\{\begin{array}{l}0.05 \\
0.1 \\
0.2\end{array}\right.$ & $\begin{array}{l}13.1 \\
14.7 \\
20.0\end{array}$ & $\begin{array}{l}0 \\
0 \\
0\end{array}$ \\
\hline Control & - & 3.2 & 0 \\
\hline
\end{tabular}

acid was produced even though alanine accumulated well.

More detailed experiments were carried out concerning the influence of the concentration of peptone and casate found to be adequate for amino acids production. In this experiment, the basal medium was as follows: glucose $10 \mathrm{~g}, \mathrm{~K}_{2} \mathrm{HPO}_{4} 0.1 \mathrm{~g}, \mathrm{MgSO}_{4} \cdot 7 \mathrm{H}_{2} \mathrm{O} 0.05 \mathrm{~g}$ and urea $0.6 \mathrm{~g}$ in $100 \mathrm{ml}$ of tap water. The results obtained are as follows (Table III) :

Table III. Influence of Peptone and Casate ON THE PRODUCTION OF AMINo ACID

\begin{tabular}{crrrc}
\multicolumn{2}{c}{ Peptone added } & & & \\
Casate added & $0 \%$ & $0.05 \%$ & $0.10 \%$ & $0.20 \%$ \\
$0 \%$ & & & & \\
0.01 & $4.7 *$ & 49.8 & 10.7 & 3.5 \\
0.02 & 10.0 & 52.7 & 22.0 & 4.0 \\
0.04 & 12.1 & 49.7 & 23.4 & 3.7 \\
0.06 & 25.8 & 47.5 & 7.3 & 4.1 \\
0.10 & 23.1 & 23.6 & 6.5 & 3.7 \\
0.20 & 5.1 & 8.0 & 5.8 & 4.0 \\
& 2.6 & 2.5 & - & 3.5
\end{tabular}

* The figures indicate the yield of alanine based on glucose added.

It was observed that the optimal concentration of peptone seemed to be $0.05 \%$ and the optimal concentration of casate was likely to lie in the range of $0.01 \sim 0.04 \%$, and peptone 
was much more effective than casate only. This fact means that the effective substances are included in peptone rather than in casate, and as the casate used here was the vitaminfree preparation, this effective substances are supposed to be a kind of vitamins.

(IV) The Vitamin Requirements for Growth.

In the previous section, it was supposed that some of the vitamins were effective for amino acids production, and in this connection the vitamin requirements of this strain for growth were examined. The minimal medium was composed of $2 \%$ of xylose, $0.1 \%$ of $\mathrm{K}_{2} \mathrm{HPO}_{4}, 0.05 \%$ of $\mathrm{MgSO}_{4} \cdot 7 \mathrm{H}_{2} \mathrm{O}$ and $0.6 \%$ of urea. Vitamin-free casamino acids and several vitamins were added to this minimal medium and the growth was determined after 18 hours' cultivation. The results are shown in Table IV. The seed culture employed in this experiment was the washed cell suspension harvested from bouillon culture.

In the absence of biotin, the growth hardly occurred and it might suggest the requirement for biotin in the growth of this strain. As for

TABLE IV. Vitamine ReQUIREMENTS FOR GROWTH

\section{M.M.}

Medium Composition

M.M.+A.A.

M.M.+A.A. + V.

"I

-Biotin

- Thiamine

-Pantothenic acid

-Nicotinic acid

-Riboflavin

-Folic acid

- $p$-Aminobenzoic acid

-Choline

-Inositol

-Pyridoxine

Growth (O.D.)

0.010

0.040

0.213

0.060

0.098

0.148

0.218

0.218

0.188

0.208

0.203

0.210

0.163

M.M. : Minimal medium.

A.A. : Vitamine-free casamino acids.

V.: All the vitamins mentioned below :

Biotin : $0.2 \mathrm{r} / \mathrm{dl}$, Thiamine : $10 \mathrm{r} / \mathrm{dl}$ (hydroxide), Pantothenic acid : $10 \mathrm{r} / \mathrm{dl}$ (Ca salt), Nicotinic acid : $50 \mathrm{r} / \mathrm{dl}$, Riboflavin : $20 \mathrm{r} / \mathrm{dl}$, Folic acid : $10 \mathrm{r} / \mathrm{dl}$, $p$-Aminobenzoic acid : $10 \mathrm{r} / \mathrm{dl}$. Choline : $500 \mathrm{r} / \mathrm{dl}$ (chloride), Inositol : $50 \mathrm{r} / \mathrm{dl}$, Pyridoxine: $10 \mathrm{r} / \mathrm{dl}$ (hydrochloride). the other vitamins, the results were not obvious.

(V) The Influence of Carbohydrates Concentration.

Xylose and glucose were employed as carbon sources and the influence of their concentration on the amino acids production was examined. The basal medium in this experiment was composed of $0.1 \mathrm{~g}$ of $\mathrm{K}_{2} \mathrm{HPO}_{4}, 0.05 \mathrm{~g}$ of $\mathrm{MgSO}_{4} \cdot 7 \mathrm{H}_{2} \mathrm{O}, 0.05 \mathrm{~g}$ of the peptone and $0.6 \mathrm{~g}$ of urea in $100 \mathrm{ml}$ of tap water. The results are shown in Fig. 2 and 3.

The tendencies were the same in both substrates, and it was found that this strain showed greater resistance to glucose than to xylose. And it was also observed that the optimal initial concentration of xylose and glucose seemed to be about $5 \%$ and $10 \%$, respectively. It seemed to be the reason why the yields of amino acids were lower when the sugar concentrations were below or above

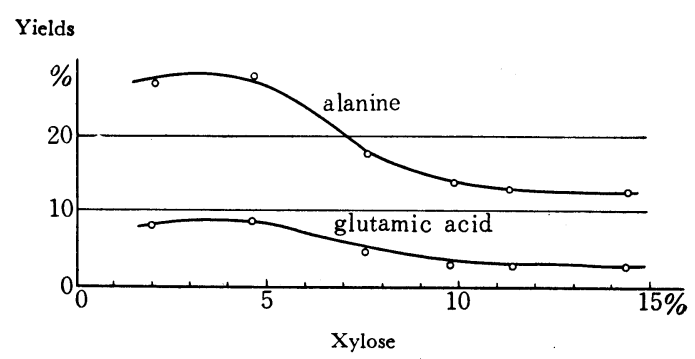

Fig. 2. Influence of Xylose Concentration on the Production of Amino Acids.

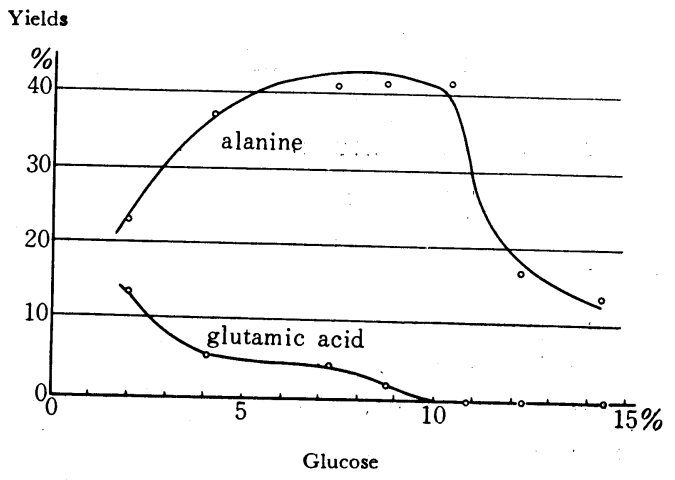

FIG. 3. Influence of Glucose Concentration on the Production of Amino Acids. 
these optimal values that the concentration of peptone was not adequate in these cases. Accordingly it should be possible to maintain higher yields of amino acids by adjusting the concentration of peptone according to the concentration of sugar.

\section{(VI) The Influence of Bulk Salts.}

As the requirements of this strain for the organic growth substances were rather low, it was supposed that the effects of inorganic salts on the amino acids production should be important, and in the following experiments the influence of bulk salts such as $\mathrm{K}_{2} \mathrm{HPO}_{4}, \mathrm{KH}_{2} \mathrm{PO}_{4}, \mathrm{MgSO}_{4} \cdot 7 \mathrm{H}_{2} \mathrm{O}$ and $\mathrm{NaCl}$ was examined.

\section{(1) Effects of $\mathrm{K}_{2} \mathrm{HPO}_{4}$.}

In this experiment, the basal medium was as follows: xylose $5 \mathrm{~g}, \mathrm{MgSO}_{4} \cdot 7 \mathrm{H}_{2} \mathrm{O} 0.05 \mathrm{~g}$, peptone $0.05 \mathrm{~g}$ and urea $0.6 \mathrm{~g}$ in $100 \mathrm{ml}$ of tap water. The results are shown in Fig. 4.

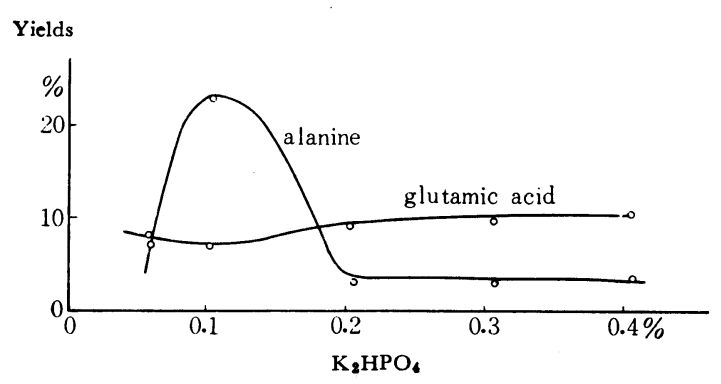

Fig. 4. Influence of $\mathrm{K}_{2} \mathrm{HPO}_{4}$ Concentration on the Production of Amino acids.

L-Glutamic acid production was rather indifferent but alanine productivity was much influenced by the concentration of $\mathrm{K}_{2} \mathrm{HPO}_{4}$ and the optimal concentration of this salts was found to be about $0.1 \%$. An excess of $\mathrm{K}_{2} \mathrm{HPO}_{4}$ resulted in the decreased yield of alanine.

(2) Effects of $\mathrm{KH}_{2} \mathrm{PO}_{4}$.

In this experiment, the basal medium was composed of $5 \mathrm{~g}$ of xylose, $0.1 \mathrm{~g}$ of $\mathrm{K}_{2} \mathrm{HPO}_{4}$, $0.05 \mathrm{~g}$ of $\mathrm{MgSO}_{4} \cdot 7 \mathrm{H}_{2} \mathrm{O}, 0.05 \mathrm{~g}$ of peptone and $0.6 \mathrm{~g}$ of urea in $100 \mathrm{ml}$ of tap water. As shown

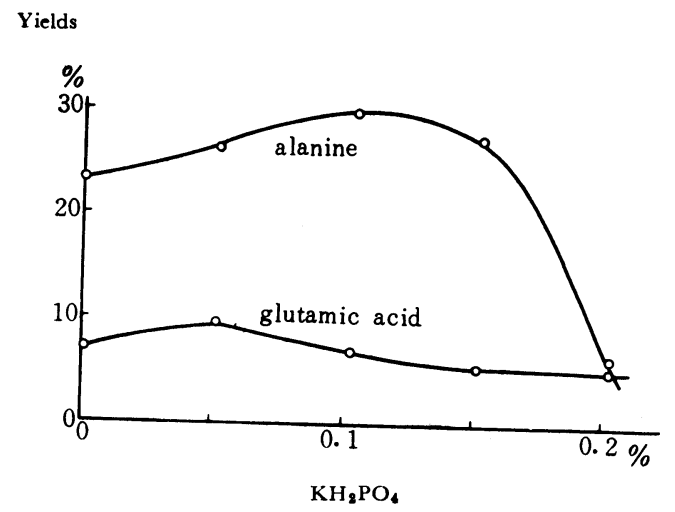

FIG. 5. Influence of $\mathrm{KH}_{2} \mathrm{PO}_{4}$ on the Production of Amino Acids.

in Fig. 5, the optimal concentration of $\mathrm{KH}_{2} \mathrm{PO}_{4}$ lies between 0.07 and $0.13 \%$ and in this case, too, an excess of it had bad effects on alanine production.

(3) Effects of $\mathrm{MgSO}_{4} \cdot 7 \mathrm{H}_{2} \mathrm{O}$.

In this experiment, the basal medium composition was $5 \mathrm{~g}$ of xylose, $0.1 \mathrm{~g}$ of $\mathrm{K}_{2} \mathrm{HPO}_{4}$, $0.05 \mathrm{~g}$ of peptone and $0.6 \mathrm{~g}$ of urea in $100 \mathrm{ml}$ of tap water. The results are as follows (Fig. 6) :

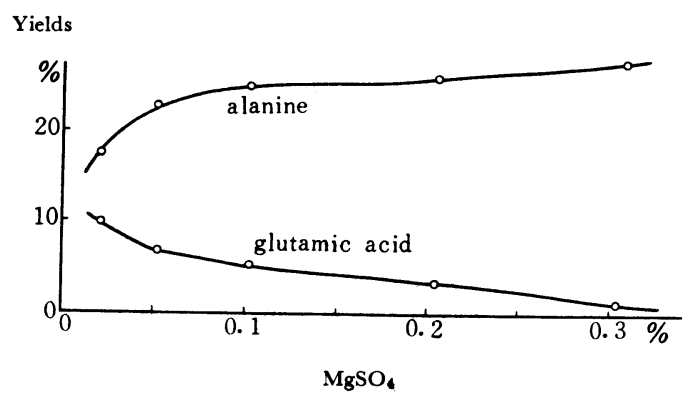

FiG. 6. Influence of $\mathrm{MgSO}_{4} 7 \cdot \mathrm{H}_{2} \mathrm{O}$ Concentration on the Production of Amino Acids.

These show that more than $0.1 \%$ of $\mathrm{MgSO}_{4} \cdot 7 \mathrm{H}_{2} \mathrm{O}$ had a favorable effect on the alanine accumulation, but as the concentration of this salts increased, the productivity of L-glutamic acid seemed to decrease.

(4) Effects of $\mathrm{NaCl}$.

In this experiments, the basal medium was 


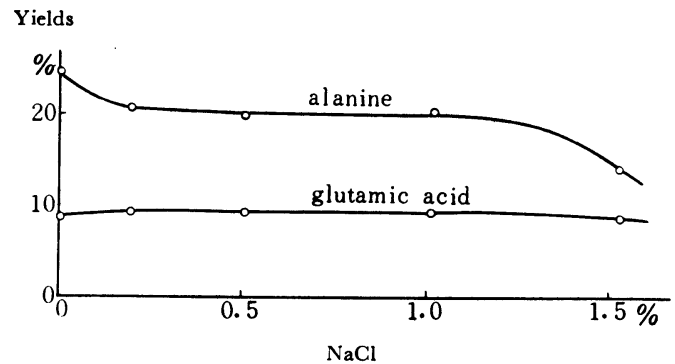

FIG. 7. Influence of $\mathrm{NaCl}$ Concentration on the Production of Amino Acids.

as follows: xylose $5 \mathrm{~g}, \quad \mathrm{~K}_{2} \mathrm{HPO}_{4} \quad 0.1 \mathrm{~g}$, $\mathrm{MgSO}_{4} \cdot 7 \mathrm{H}_{2} \mathrm{O} 0.05 \mathrm{~g}$, peptone $0.05 \mathrm{~g}$ and urea $0.6 \mathrm{~g}$ in $100 \mathrm{ml}$ of tap water.

No stimulatory effect was observed as shown in Fig. 7.

(VII) The Influence of Trace Elements.

The effects of eight metals on the amino acids production were examined. Basal medium employed was as follows: xylose $5 \%$, $\mathrm{K}_{2} \mathrm{HPO}_{4} 0.1 \%, \mathrm{MgSO}_{4} \cdot 7 \mathrm{H}_{2} \mathrm{O} 0.05 \%$, peptone $0.05 \%$ and urea $0.6 \%$.

The results appear in Table V. It was observed that $\mathrm{Mn}^{++}$gave a marked stimulation but $\mathrm{Ni}^{++}, \mathrm{Cu}^{++}, \mathrm{Zn}^{++}$and $\mathrm{Cd}^{++}$had poisonous effects. $\mathrm{Fe}^{+++}, \mathrm{Mo}^{++}$and $\mathrm{Co}^{++}$ had no noticeable influences.

(VIII) The Influence of Oxygen Supply.

In order to investigate the influence of oxygen supply on the amino acids formation, the following experiments were carried out. The medium employed was composed of $5 \mathrm{~g}$ of xylose, $0.1 \mathrm{~g}$ of $\mathrm{K}_{2} \mathrm{HPO}_{4}, 0.05 \mathrm{~g}$ of $\mathrm{MgSO}_{4} \cdot 7 \mathrm{H}_{2} \mathrm{O}, 0.05 \mathrm{~g}$ of peptone and $0.6 \mathrm{~g}$ of urea in $100 \mathrm{ml}$ of tap water. Incubation was performed with several volumes of this medium in $500 \mathrm{ml}$ flasks using a reciprocal shaker (70 mm stroke) at a rate of 144 r.p.m. at $30^{\circ} \mathrm{C}$. The extent of oxygen supply was expressed by the oxygen adsorption coefficients, $\mathrm{Kd}$ [g mol of $\mathrm{O}_{2} / \mathrm{ml} \mathrm{min} \mathrm{atm]} \mathrm{determined} \mathrm{by}$ the sulfite methods ${ }^{5}$.

The results are shown in Fig. 8.

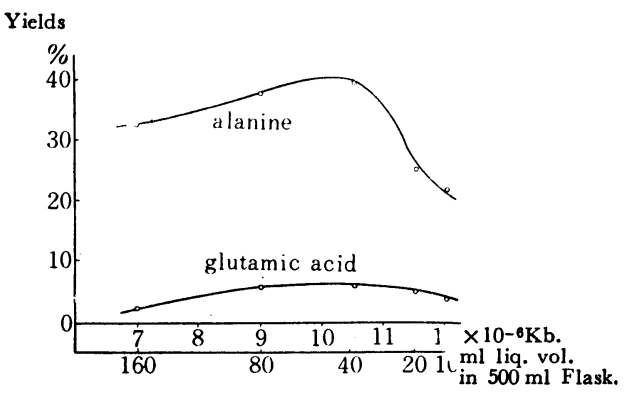

FiG. 8. Influence of Oxygen Supply on the Production of Amino Acids.

It was obvious that the aerobic condition was preferable for this fermentation but too high oxygen supply was not adequate. The recommended rate of oxygen supply was performed when about $40 \mathrm{ml}$ of the medium was

Table V. Influence of Trace Elements on the Production of Amino Acids

\begin{tabular}{llc} 
Elements & \multicolumn{2}{c}{ Compound added } \\
$\mathrm{Fe}^{+++}$ & $\mathrm{Fe}_{2}\left(\mathrm{SO}_{4}\right)_{3}$ & $10 \mathrm{ppm}$ \\
$\mathrm{Mn}^{++}$ & $\mathrm{MnSO}_{4} \cdot 7 \mathrm{H}_{2} \mathrm{O}$ & $\prime \prime$ \\
$\mathrm{Mo}^{6+}$ & $\mathrm{Na}_{2} \mathrm{MoO}_{4}$ & $\prime \prime$ \\
$\mathrm{Co}^{++}$ & $\mathrm{CoSO}_{4} \cdot 7 \mathrm{H}_{2} \mathrm{O}$ & $\prime \prime$ \\
$\mathrm{Ni}^{++}$ & $\mathrm{NiSO}_{4} \cdot 7 \mathrm{H}_{2} \mathrm{O}$ & $\prime \prime$ \\
$\mathrm{Cu}^{++}$ & $\mathrm{CuSO} \cdot 5 \mathrm{H}_{2} \mathrm{O}$ & $\prime \prime$ \\
$\mathrm{Zn}^{++}$ & $\mathrm{ZnSO}_{4} \cdot 7 \mathrm{H}_{2} \mathrm{O}$ & $\prime \prime$ \\
$\mathrm{Cd}^{++}$ & $\mathrm{CdSO}_{4} \cdot 7 \mathrm{H}_{2} \mathrm{O}$ & $\prime \prime$ \\
Control & - & -
\end{tabular}

Growth
+
+
+
+
+
+
+
-
+

Yields based on the sugar added

5) K. Yamada, J. Takahashi and H. Okada, J. Agr. Chem. Soc. Japan, 27, 704 (1953).

$\begin{array}{cc}\text { Alanine } \% & \text { Glutamic acid \% } \\ 7.8 & 14.3 \\ 20.5 & 12.4 \\ 11.7 & 12.6 \\ 9.8 & 4.9 \\ 0 & 0 \\ 0 & 0 \\ 0 & 0 \\ 0 & 0 \\ 9.3 & 14.4\end{array}$


employed in $500 \mathrm{ml}$ flask under the condition mentioned above. This recommended rate corresponds to $9 \sim 10 \times 10^{-6} \mathrm{Kd}$.

\section{(IX) Course of the Fermentation.}

An example of the time-course studies of this fermentation is shown in Fig. 9. The medium used was composed of $5 \mathrm{~g}$ of xylose, $0.1 \mathrm{~g}$ of $\mathrm{K}_{2} \mathrm{HPO}_{4}, 0.05 \mathrm{~g}$ of $\mathrm{MgSO}_{4} \cdot 7 \mathrm{H}_{2} \mathrm{O}$, $0.05 \mathrm{~g}$ of peptone and $0.6 \mathrm{~g}$ of urea in $100 \mathrm{ml}$ of tap water.

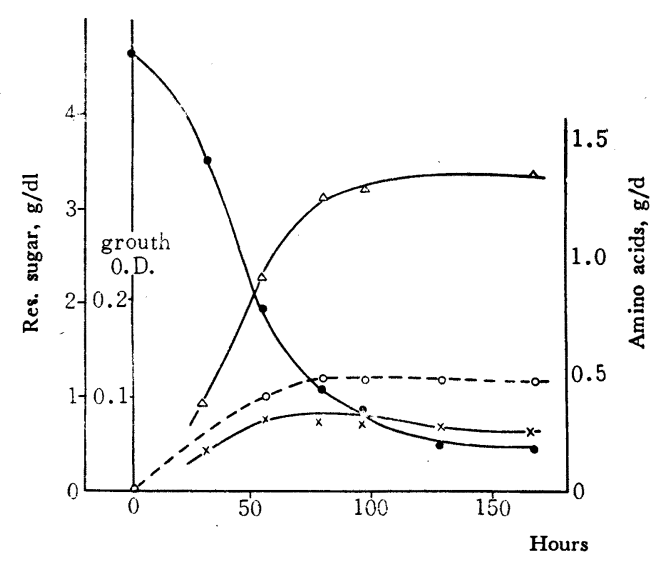

Fig. 9. An Example of this Amino Acids

$$
\begin{array}{ll}
\text { Fermentation. } \\
\triangle-\triangle-\triangle & \text { alonine } \\
\triangle-\triangle-\triangle & \text { growth } \\
-\times-\triangle-\times & \text { glutamic acid }
\end{array}
$$

By-products such as acetic acid and pyruvic acid were detected in the culture broth. Alanine produced by this fermentation was identified to be a racemic form by the infra-red analysis and also by the biological method using D-amino acids oxidase.

\section{SUMMARY}

In order to find out the proper conditions for the fermentative production of the amino acids by Brevibacterium pentoso-aminoacidicum nov. sp., the effects of several factors were studied.

Nitrogen sources such as $\mathrm{NH}_{4} \mathrm{Cl},\left(\mathrm{NH}_{4}\right)_{2} \mathrm{SO}_{4}$ and urea were examined as to their adequacy for the production of amino acids by this strain and urea was found to be the best of all compounds tested. The proper range of the concentration of this nitrogen source was determined to be 0.6 to $0.8 \%$.

As for the growth substances, peptone and casate were shown to have excellent effects in the concentration of about $0.05 \%$ and it was also found that this strain required biotin for its growth.

The proper concentration of carbon sources, xylose and glucose, were found to be about $5 \%$ and $10 \%$, respectively.

The effects of several minerals including bulk salts and trace elements were also discussed. The adequate concentration of $\mathrm{K}_{2} \mathrm{HPO}_{4}, \mathrm{KH}_{2} \mathrm{PO}_{4}$ and $\mathrm{MgSO}_{4} \cdot 7 \mathrm{H}_{2} \mathrm{O}$ were about $0.1 \%$, and $\mathrm{Mn}^{++}$showed a marked stimulating effect on the amino acids production.

The aerobic condition was favorable for growth and amino acids production and the desirable degree of oxygen supply was determined to be about $9 \sim 10 \times 10^{-6} \mathrm{Kd}$ [ $\mathrm{g}$ mol of $\mathrm{O}_{2} / \mathrm{ml}$ min atm].

Alanine produced by this fermentation was found to be a racemic form. 